\title{
Biodegradation of plastic wastes by confused flour beetle Tribolium confusum Jacquelin du Val larvae
}

\author{
Hind Suhail Abdulhay* \\ Department of Biology, College of Science, University of Baghdad, Baghdad, Iraq
}

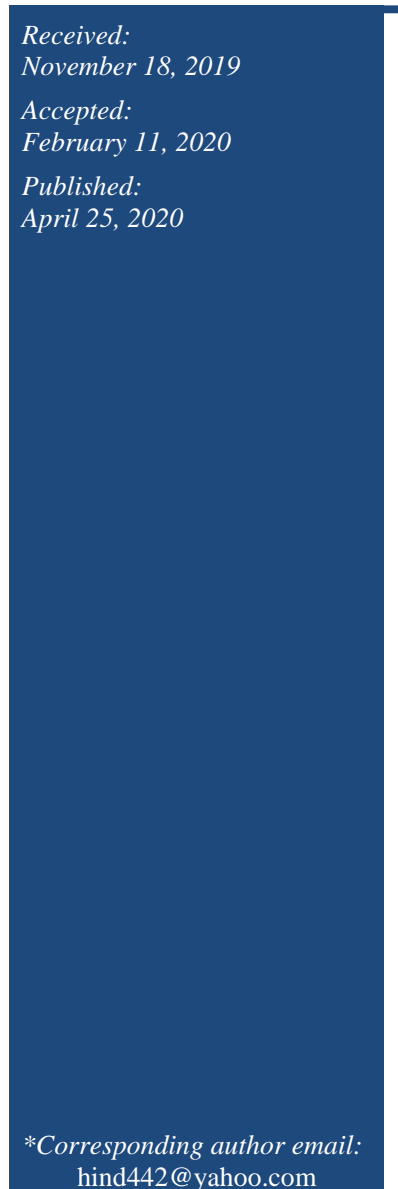

\begin{abstract}
As a consequence of increasing the production of plastics which accumulate substantial quantities of plastic wastes in the natural environment and in landfills that could persist for centuries. The ability of confused flour beetle Tribolium confusum larvae to consume and biodegrade different types of plastics were investigated. The experiment was performed by starving the larvae then exposed to three different types of plastic (polystyrene (PS), polyethylene foam (PE), and ethylene-vinyl acetate (EVA) as diet in comparison to larvae reared on the conventional diet of wheat flour. The larvae were monitored under controlled conditions then the survival rate, the mass losses for both larvae and plastics resulting from the diet on plastic as a function of time $(1,14,21$ and 30 days) were measured. The results showed that with the increase of time; the averages of larvae survival on all types of plastic were decreased compared with control. The highest larval survival rate was found in the PS diet (70\%), while the least was with larvae fed on EVA (30\%) after 30 days. Decreasing in the mass weight of the larvae was confirmed during the study, which indicates that plastic materials are not an efficient source of energy for larvae except their survival. The mass loss was 26.2, 31.4 and $45.8 \%$ recorded for larvae fed on PS, PE, and EVA respectively. The study recorded that $T$. confusum has the ability to degradation plastic, which can reduce the pollution caused by different types of plastic wastes.
\end{abstract}

Keywords: Tribolium confusum, Biodegradation, Plastic waste, FTIR

How to cite this:

Abdulhay HS, 2020. Biodegradation of plastic wastes by confused flour beetle Tribolium confusum Jacquelin du Val larvae. Asian J. Agric. Biol. 8(2):201-206. DOI: https://doi.org/10.35495/ajab.2019.11.515

This is an Open Access article distributed under the terms of the Creative Commons Attribution 3.0 License. (https://creativecommons.org/licenses/by/3.0), which permits unrestricted use, distribution, and reproduction in any medium, provided the original work is properly cited.

\section{Introduction}

Plastic waste is one of the most severe and common environmental problems in the world in this era. Increased use and slow biodegrading have led to accumulating plastic waste in the outdoor environment in large quantities, as parts of municipal solid waste also dispersed as "white pollutants"
(Cózar et al., 2014; Jambeck et al., 2015). The long term accumulations of non-biodegradable polymers lead to many ecological and health problems, especially the marine (Przybylinska and Wyszkowski, 2016) and terrestrial environment (Zhao et al., 2016). Further, plastic and its chemical compounds might have considerable concern about the adverse effects of these chemicals on wildlife as well as human health 
(Kobrosly et al., 2014). Today the environmental hazards and risks from these chemicals associated with the plastic products are diversified with significant efforts to minimize plastic pollution, by reducing the consumption of plastic and encourage plastic recycling.

Polystyrene (PS) commonly known as styrofoam, is made from the monomer styrene. It is a synthetic aromatic hydrocarbon polymer which can be solid or foamed (Scheirs and Priddy, 2003). PS is durable and inexpensive materials used in various products such as food preservation containers, lids, trays, bottles, and disposable cutlery and the making of models. Polyethylene foam (PE) is an ordinary plastic polymer, which has a high load-bearing capacity. It is used to protect sensitive electronic products and material as shock absorbing, vibration dampening, insulation, barrier or buoyancy component, and as a material for cushioning products in packaging applications. Ethylene-vinyl acetate (EVA) is a thermoplastic copolymer derived from petroleum known as expanded rubber or foam rubber. EVA is materials like rubber in flexibility and softness used as a shock absorber material; packaging, textile, metal surfaces, coated paper, and cement render (Coto et al., 2012).

Degradation of plastic can be defined as any chemical or physical change in the polymer due to the effect of environmental factors, such as heat, light, moisture, chemical conditions or biological activity (Kale et al., 2015). Recent studies have focused on the ability of microorganisms including certain bacteria and fungi in biodegradation of polymers through different exoenzymes responsible under stress conditions (Ahmed, 2018). While studies on the ability of insects to degrade plastics are very limited and constricted. Insect pests, including red flour beetles Tribolium castaneum, cigarette beetles Lasioderma serricorne, cadelle beetles Tnebrioide mauretanicus, Zophobas morio, etc. and several moths and their larvae, also may degrade different plastic packing materials (Newton,1988; Bombelli et al., 2017). Thus, the present study designed to investigate the efficiency of confused flour beetle, Tribolium confusum to degrade three types of plastic (PS, PE, EVA).

\section{Material and Methods}

\section{Insect collection}

The larval populations of confused flour beetle were collected from infested wheat godowns into glass containers for further rearing at a constant temperature of $30{ }^{\circ} \mathrm{C}$ and $70 \pm 5 \%$ R.H in continuous darkness (Abdulhay, 2012). The adults were moved to a new rearing media every week for further experiments.

\section{Plastic collection}

Three types of plastics collected in the study:

-Polystyrene (PS): Collected from disposable food storage containers (PS no.6).

-Polyethylene foam (PE): Obtained from the remaining electrical equipment packaging, used for electrical appliances to protect during transportation.

-Ethylene-vinyl acetate: Collected from the plastic on the car doors to protect against shocks.

All the plastics were cut into small discs with a diameter of $1 \mathrm{~cm}$ and a height of $1 \mathrm{~mm}$, washed with distilled water and left to dry for at least a single day.

\section{Experimental procedure}

To investigate the ability of flour beetle $T$. confusum larvae to live, feed and survival on plastics; larvae almost with similar mass were starved for $24 \mathrm{~h}$ and then placed into small plastic tubes $(3.5 \mathrm{~cm}$ diameter and $5 \mathrm{~cm}$ height) containing two plastic dices from the same type. The experiment was carried out in four groups with ten larvae specimens for each as follows: -Larvae fed on polystyrene (PS).

-Larvae fed on polyethylene foam (PE).

-Larvae fed on ethylene-vinyl acetate (EVA).

-Larvae feed on wheat flour as a typical diet considered as control.

The larvae were fed with the three types of plastic as their sole diet for 30 days. Before every experiment, the larvae and plastic discs were weighted. All the larvae were kept under the same conditions of rearing and monitored for 30 days. During the experiments, dead larvae and molted skins were removed immediately, and the survival was counted and weighted each week to determine the mass losses resulting from larvae diet on plastic as a function of time, compared to control. All tests were carried out in triplicate for each test.

\section{Chemical group analysis (FTIR)}

Functional groups responsible for linking ions were investigated by using Fourier Transform Infrared spectrophotometers (FTIR-8400) Shimadzu (Japan). Peaks were identified after recording the spectra from the residual plastics before and after larvae feeding. 


\section{Statistical analysis}

The results were analyzed according to the complete random design of the experiments. All data were performed using one-way analysis of variance (ANOVA) and the least significant differences (LSD).

\section{Results and Discussion}

\section{Measurement the survival ratio of $T$. confusum larvae}

Based on data shown in table (1); we can find that $T$. confusum larvae fed on the three types of plastics: polystyrene (PS), polyethylene foam (PE), and ethylene-vinyl acetate (EVA) during one month. In general, the number of larvae did not change in the first week. While increasing in time; the average of larvae numbers for all types of plastics decreased compared to control. After 30 days from the beginning of experiments, the number of survival $T$. confusum larvae fed on PS, PE, and EVA were $70 \pm 4.0,50 \pm 2.45$ and $30 \pm 6.04$, respectively. No significant differences $(\mathrm{P}<0.05)$ were found between the different feeding and control after 7 days $(100 \pm 0.0)$; also no significant differences were found between the number of survival larvae fed on PS and PE after 14 and 21 days from the experiment (Table 1).

Table-1: Survival rates of $T$. confusum larvae after 7, 14, 21 and 30 days of feeding on the different type of plastic

\begin{tabular}{|c|c|c|c|c|}
\hline \multirow{2}{*}{$\begin{array}{c}\text { Plastic } \\
\text { type }\end{array}$} & \multicolumn{4}{|c|}{$\begin{array}{c}\text { No. of survival T. confusum larvae } \\
\text { mean } \pm \text { S.D }(\%)\end{array}$} \\
\cline { 2 - 5 } & $\mathbf{7}$ day & $\mathbf{1 4}$ day & $\mathbf{2 1}$ day & $\mathbf{3 0}$ day \\
\hline Control & $100 \pm 0.0 \mathrm{a}$ & $100 \pm 0.0 \mathrm{a}$ & $90 \pm 6.01 \mathrm{a}$ & $90 \pm 6.01 \mathrm{a}$ \\
\hline PS & $100 \pm 0.0 \mathrm{a}$ & $90 \pm 6.01 \mathrm{~b}$ & $75 \pm 4.82 \mathrm{~b}$ & $70 \pm 4.0 \mathrm{~b}$ \\
\hline PE & $100 \pm 0.0 \mathrm{a}$ & $81 \pm 5.5 \mathrm{~b}$ & $65 \pm 3.76 \mathrm{~b}$ & $50 \pm 2.45 \mathrm{c}$ \\
\hline EVA & $100 \pm 0.0 \mathrm{a}$ & $70 \pm 4.82 \mathrm{c}$ & $40 \pm 7.30 \mathrm{c}$ & $30 \pm 6.04 \mathrm{~d}$ \\
\hline $\mathrm{LSD}_{(\mathrm{p}<0.05)}$ & 8.23 & 9.0 & 12.45 & 18.10 \\
\hline
\end{tabular}

- Mean values followed by the same letter within a column are not significantly different.

Current findings agreed with previously mentioned that mealworms fed solely on polystyrene were able to survive for two months. This ability for polystyrene biodegradation was due to the activity and role of bacteria found in mealworms gut (Yang et al., 2015). Several genera of bacteria have been identified from mealworms gut such as Lactococcus, Weissella, Spiroplasma, Rahnella, Cronobacter, Enterococcus, Lactobacillus, Bacillus, Enterobacter, Clostridium and Pantoea (Wang and Zhang, 2015). In the gut of $T$. confusum, not only bacteria might exist but also various other microbes such as fungi and yeast. Some of fungi taxa are Saccharomycetales, Capnodiales Botryosphaeriales, Hypocreales, Xylariales, Chaetothyriales, and Pleosporales have been isolated from these beetles (Rojas-Jiménez and Hernández, 2015). Also, some Spiroplasma spp. known as insect pathogen effects on the larvae of $T$. confusum without causing any harm (Jung et al., 2014). Although it is difficult to know which microbial genera or families are responsible for the degradation of polystyrene because only a few degrading bacteria have been isolated.

Measurement the mass changes in $T$. confusum larvae and the plastic materials

Table (2) showed the differences in the weight of $T$. confusum larvae fed on the three types of plastic (polystyrene (PS), polyethylene foam and EVA). Mass losses in larvae weight increased throughout the study from the initial mass $0.42 \pm 0.92,0.35 \pm 1.01$ and $0.31 \pm 1.20 \mathrm{mg}$, the final mass at the end of the experiment was $0.31 \pm 0.75,0.24 \pm 0.98$ and $0.17 \pm 1.05$ $\mathrm{mg}$ for larvae fed on the types mentioned before, respectively.

Table-2: The Mass losses in the weight of $T$. confusum larvae and the plastic materials after 30 days

\begin{tabular}{|c|c|c|c|c|}
\hline \multirow{2}{*}{$\begin{array}{c}\text { Plastic } \\
\text { type }\end{array}$} & $\begin{array}{c}\text { Tnitial } \\
\text { weight } \\
\text { (mg) }\end{array}$ & $\begin{array}{c}\text { Final } \\
\text { Weight } \\
\text { (mg) }\end{array}$ & $\begin{array}{c}\text { Mass loss } \\
\text { after 30 } \\
\text { days (\%) }\end{array}$ & $\begin{array}{c}\text { Mass loss } \\
\text { in plastic } \\
\text { materials } \\
\text { after 30 } \\
\text { days (\%) }\end{array}$ \\
\hline PS & $0.42 \pm 0.92$ & $0.31 \pm 0.75$ & $26.2 \mathrm{a}$ & $51.92 \mathrm{a}$ \\
\hline PE & $0.35 \pm 1.01$ & $0.24 \pm 0.98$ & $31.4 \mathrm{a}$ & $46.84 \mathrm{a}$ \\
\hline & & & $45.2 \mathrm{~b}$ & $2.9 \mathrm{~b}$ \\
\cline { 4 - 5 } EVA & $0.31 \pm 1.20$ & $0.17 \pm 1.05$ & $\mathrm{LSD}_{(\mathrm{P}<0.05)}$ & $\mathrm{LSD}_{(\mathrm{P}<0.05)}$ \\
& & & 7.33 & 5.50 \\
\hline
\end{tabular}

The results showed that the weight of $T$. confusum larvae gradually decreased, where the highest mass loss of larvae for EVA consumption after 30 days was $45.2 \%$. Meanwhile, $26.2 \%$ was the lowest mass loss was of larvae feed on PS (Table 2). No significant differences were found between the mass loss in larvae fed in PS and PE ( $p>0.05)$ after 30 days. The observation throughout the study revealed that $T$. confusum larvae started to eat the PS then make a hole inside the plastic disk (Figure 1). 


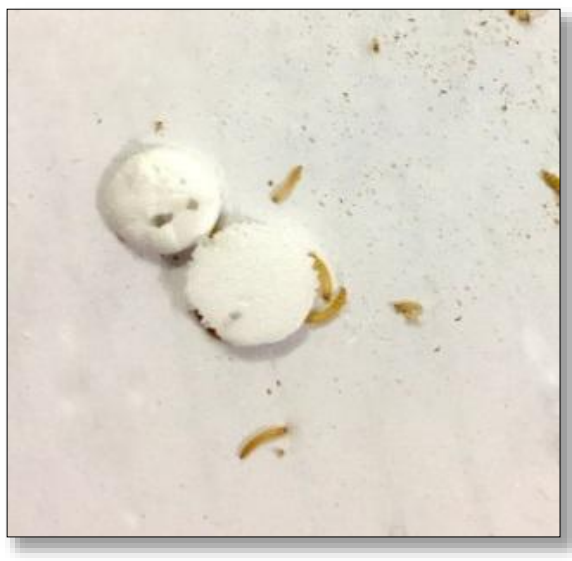

Figure-1: The holes of confused flour beetle, Tribolium confusum inside polystyrene (PS)

Furthermore, the results from table 2 conducted that polystyrene (PS) loss the highest mass $(50.92 \%)$, suggesting that the larvae ingest this type of plastics as food. While the lowest mass loss concerning the mass of EVA, although a small but noticeable mass loss $(2.9 \%)$ was recorded after 30 days of exposure to larvae, which may be probably due to the unavailability and difficulty of this material to $T$. confusum larvae. Among the three types of plastic, the significant differences $(p<0.05)$ were found only between mass loss of PS, PE and EVA, However, again no significant differences were found between PS and PE. Ethylene-vinyl acetate is one of the most challenging materials for biodegradation exhibit strong durability, high flexibility, low-temperature toughness, stress crack resistance and hot-melt adhesive waterproof properties (Stael et al., 2005). Also, it may be exciting and promising in the context of further studies.

The degradation efficiency of PE's can be directly measured by the sample weight loss, as the depolymerization of materials can be observed by the formation of lower molecular weight compounds and molecular weight shift (Yang et al., 2014). Previous studies conducted the ability of insect larvae to chew and damage polyethylene, polyester and PVC films despite whether it was used to cover food, indicating that insect larvae may also eat and ingest plastics as food (Cline, 1978). Riudavets et al. (2007) mentioned the ability of some mandibulate insects to chew some plastic packages films, including polyethylene (PE), polyvinyl chloride (PVC), and polypropylene (PP).

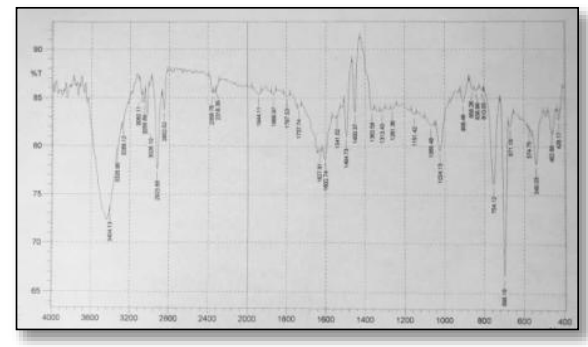

(A) Polystyrene sample before larvae consumption (Control)

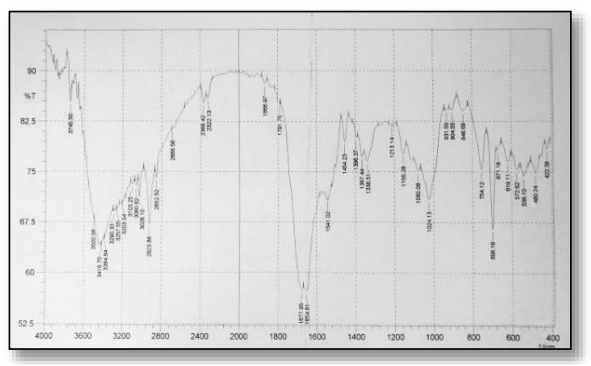

(B) Polystyrene residual after 30 days from consumption

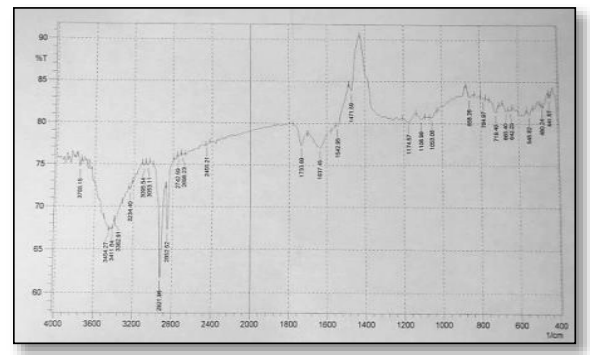

(C) Polyethylene sample before larvae consumption (Control)

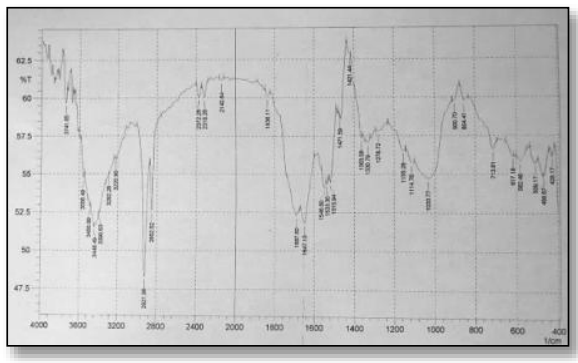

(D) Polyethylene residual after 30 days from consumption

Figure-2: FTIR (A, B, C, D) spectra of polystyrene and polyethylene before and after larvae consumption 


\section{Hind Suhail Abdulhay}

Elijah et al. (2015) used comparative biodeterioration of nylon by tested three species: Tribolium, Sitophilus and Oryzaephilus using three plastic types for 6 weeks. Results showed that the number of borings or holes (as an index of biodeterioration) increased and Oryzaephilus has the most active holes after 6 weeks. Other studies suggested the adaptability of the mealworm Tenebrio molitor L. gut microbiome enables degradation of styrofoam chemically dissimilar plastics effectively (Brandon et al., 2018). Different organisms need to mineralize large polymers into carbon dioxide and its constituent monomers as simple byproducts. Yang et al. (2014) mentioned that Plodia interpunctella and Galleria mellonella larvae could chew and degrade PE films. It is essential to mention that at the end of our experiments, some larvae completed their life cycle and transformed the pupae stage.

\section{FTIR analysis}

FTIR spectra of the samples are presented in (Fig. 2). The results of polystyrene after larvae consumption (Fig. 2.b) indicates the appearance of new absorption bands at $3500-2400 \mathrm{~cm}^{-1}$ for hydroxyl groups $(\mathrm{OH})$ and hydrogen bonding (Guilhaumou and Dumas, 2005). Moreover, a new absorption band at $1677 \mathrm{~cm}^{-1}$ for carboxylic acid (CO) or amide compound. Aliphatic group $(\mathrm{CH})$ at $2923-2852 \mathrm{~cm}-1$ and aromatic $(\mathrm{CC})$ at $1541 \mathrm{~cm}-1$ were found in polystyrene after consumption. The polyethylene foam control sample showed the presence of $\mathrm{NH}$ group at $3100-3500 \mathrm{~cm}^{-1}$ and the same bond reflected at $1640-1560 \mathrm{~cm}^{-1}$. (CC) bond stretch was observed at $2100 \mathrm{~cm}^{-1}$. Aliphatic group $(\mathrm{CH})$ in $\mathrm{CH}_{2}$ and $\mathrm{CH}_{3}$ groups at $2900-2850 \mathrm{~cm}^{-}$ 1 and carbonyl group at $1650-1850 \mathrm{~cm}^{-1}$ were indicated (Ali et al., 2012). Regarding sample control, the variation in bond shape, width and peaks intensity were found in all bonds after larvae consumption. Amide bond $(\mathrm{CONH})$ found in natural polymers can be hydrolyzed by proteolytic enzymes. The appearance of carbonyl groups is an essential sign of $\mathrm{PE}$ biodegradation which has demonstrated in a previous study on PE degradation (Arutchelvi et al., 2008).

\section{Conclusion}

We concluded that the confused flour beetle, Tribolium confusum has the ability for biodegradation different types of plastic (PS, PE, and EVA) so the distribution of this insect in a diverse geographic region as a cosmopolitan can help to assist plastic biodegradation and minimize the massive amount of plastic wastes.

\section{Disclaimer: None. \\ Conflict of Interest: None. Source of Funding: None.}

\section{References}

Abdulhay HS, 2012. Insecticidal Activity of Aqueous and Methanol Extracts of Apricot Prunus armeniaca L. Kernels in the Control of Tribolium confusum Duval (Coleoptera: Tenebrionidae. AlMustansiriyah J. Sci. 23: 7- 18.

Ahmed T, 2018. Biodegradation of plastics: current scenario and future prospects for environmental safety. Environ. Sci. Pollut. Res. Int. 25: 72877298.

Ali HR, El-Gendy NS, Moustafa YM, Roushdy MI and Hashem AH, 2012. Degradation of asphaltenic fraction by locally isolated halotolerant bacterial strains. ISRN Soil Sci. 2012. doi:10.5402/2012/435485.

Arutchelvi J, Sudhakar M, Arkatkar A, Dolbe M, Bhaduri S and Uppara PV, 2008. Biodegradation of polyethylene and polypropylene, Indian $\mathrm{J}$. Biotechnol. 7: 9- 22.

Bombelli P, Howe CJ and Bertocchini F, 2017. Polyethylene bio-degradation by caterpillars of the wax moth Galleria mellonella. Curr. Biol. 27: 292- 293.

Brandon Am, Gao Sh, Tian R, Ning D, Yang SS, Zhou J, Wu WM and Criddle CS, 2018. Biodegradation of polyethylene and plastic mixtures in mealworms (larvae of Tenebrio molitor) and effects on the gut microbiome. Environ. Sci. Technol. 52: 6526- 6533.

Cline LD, 1978. Penetration of seven common flexible packaging materials by larvae and adults of eleven species of stored product insects. J. Eco. Entomol. 71: 726- 729.

Coto NP, Meira JBC, Dias RB, Driemeier L, Roveri GO and Noritomi PY, 2012. Assessment of nose protector for sport activities: Finite element analysis. Dent. Traumatol. 28: 108- 113.

Cózar A, Echevarría F, González-Gordillo JI, Irigoien X, Palma ÁT, Navarro S, J García-de-Lomas, Ruiz A, Fernández-de-Puelles ML and Duarte CM, 2014. Plastic debris in the open ocean. Proc. 
Natl. Acad. Sci. 111: 10239- 10244.

Elijah I, Ohimain EI, Bawo DD, Ere D and Peters EN, 2015. Biodeterioration of plastics by weevils; an environmental and stored food product perspective. Int. J. Geol. Agric. Environ. Sci. 3: 51- 55.

Guilhaumou N and Dumas P, 2005. Synchrotron FTIR hydrocarbon fluid inclusions microanalysis applied to digenetic history and fluid flow reconstruction in reservoir appraisal. Oil Gas Sci. Technol. Rev. IFP. 60: 763- 779.

Jambeck JR, Geyer R, Wilcox C, Siegler TR, Perryman M, Andrady A, Narayan R and Law $\mathrm{KL}, 2015$. Plastic waste inputs from land into the ocean. Sci. 347: 768-771.

Jung J, Heo A, Park WY, Kim YJ, Koh H and Park W, 2014. Gut microbiota of Tenebrio molitor and their response to environmental change. Microbiol. Biotechnol. 24: 888- 897.

Kale SK, Deshmukh AG, Dudhare MS and Patil VB, 2015. Microbial degradation of plastic: a review. J. Biochem. Tech. 6: 952- 961.

Kobrosly RW, Evans S, Miodovnik A, Barrett ES, Thurston SW, Calafat AM and Swan SH, 2014. Prenatal phthalate exposures and neurobehavioral development scores in boys and girls at 6-10 years of age. Environ. Health Perspect. 122: 521- 528.

Newton J, 1988. Insects and packaging-a review. Int. Biodeterior. 24: 175- 187.

Przybylinska PA and Wyszkowski M, 2016. Environmental contamination with phthalates and its impact on living organisms. Ecol. Chem. Eng. S. 23:347-356.

Riudavets J, Salas I and Pons MJ, 2007. Damage characteristics produced by insect pests in packaging film. J. Stored Prod. Res. 43: 564- 570.
Rojas-Jiménez K and Hernández M, 2015. Isolation of fungi and bacteria associated with the guts of tropical wood-feeding Coleoptera and determination of their lignocellulolytic activities. Int. J. 2015. https://doi.org/10.1155/2015/285018.

Scheirs J and Priddy D, 2003. Modern styrenic polymers: polystyrenes and styrenic copolymers. John Wiley \& Sons Ltd, Chichester, United Kingdom.

Stael GC, Rocha MCG, D'almeida JRM and Ruiz NMDS, 2005. Analysis of the mechanical properties and characterization by solid state $13 \mathrm{c}$ NMR of recycled EVA copolymer/ silica composites. Mat. Res. 8: 269- 273.

Wang $\mathrm{Y}$ and Zhang $\mathrm{Y}$, 2015. Investigation of gutassociated bacteria in Tenebrio molitor (Coleoptera: Tenebrionidae) larvae using culturedependent and DGGE methods. Annals Entomol. Soc. Am. 108: 941- 949.

Yang J, Yang Y, Wu WM, Zhao J and Jiang L, 2014. Evidence of polyethylene biodegradation by bacterial strains from the guts of plastic-eating waxworms. Environ. Sci. Technol. 48: 1377613784.

Yang Y, Yang J, Wu WM, Zhao J, Song Y, Gao L, Yang R and Jiang L, 2015. Biodegradation and mineralization of polystyrene by plastic-eating mealworms: Part 1. Chemical and physical characterization and isotopic tests. Environ. Sci. Technol. 49: 12080- 12086.

Zhao S, Zhu L and Li D, 2016. Microscopic anthropogenic litter in terrestrial birds in Shanghai, China: Not only plastics but also natural fibers. Sci. Total Environ. 550: 11101115 . 